\title{
Continuing Professional Development and Accounting Academics: A Literature Review
}

\author{
Muhammad Umar Draz (Corresponding author) \\ Department of Management and Humanities \\ Universiti Teknologi PETRONAS \\ 32610 Bandar Seri Iskandar, Perak Darul Ridzuan, Malaysia \\ Tel: +60-5-368-7732Ｅ-mail: umardraz2626@gmail.com
}

Fayyaz Ahmad

School of Economics, Lanzhou University

Lanzhou, Gansu, China

Received: October 31, 2017 Accepted: November 21, 2017 Published: November 28, 2017

doi:10.5296/ijld.v7i4.12089 URL: https://doi.org/10.5296/ijld.v7i4.12089

\begin{abstract}
Continuing professional development (CPD) plays an important role in maintaining professional competency of the accounting academics. The main aim of undertaking CPD is to acquire new technical knowledge pertaining to a certain profession. This study intends to investigate the existing literature on CPD of accounting academics. In reviewing the relevant literature, we have particularly concentrated on these journals: 1) Accounting Education; 2) Journal of Accounting Education; 3) Teachers and Teaching; and 4) Teaching and Teacher Education. The available studies have been classified into three categories and recommendations for the future research work are provided.
\end{abstract}

Keywords: accounting academics, accountants, CPD, teachers 


\section{Introduction}

The International Federation of Accountants (IFAC) requires professional accountants to continuously acquire and maintain their professional knowledge and skills (Berg, 2007). Therefore, a person can only claim to be a professional accountant if he/she fulfills this requirement of IFAC. Since an accounting qualification is required to become a professional accountant, academics play an important role in imparting required knowledge to the future professional accountants. In order to equip the students with necessary professional competency, academics themselves need to acquire the desired knowledge first.

The existing literature mostly addresses the professional development of school teachers, CPD of professional accountants and as well as the CPD of accounting academics. This study is intended to review the available literature, determine the research gap regarding CPD of accounting academics and recommend the areas of future research work. In line with the current studies on CPD, we have divided our review on professional development into three categories, i.e. professional development of teachers, accounting professionals and accounting academics.

\section{Professional Development of Teachers}

In teaching profession, the expectations of teachers and students have been changing with the passage of time. The rapid change of literary standards and high performance expectations from students, sometimes, force teachers to develop the modern age teaching skills and work collectively to respond to the challenges of modern society. The present age of modernism demands high professional skills of teachers to satisfy the students, their parents and the institutions for which they are offering services. Therefore, in postmodern age of professionalism, teachers are dealing with a vulnerable and complex situation with an increasing influence from several pressure groups to demand an efficient and significantly trained group of teachers for their kids (Hargreaves, 2000). Cervero (2001) documented that trends in continuous education changed largely during the last couple of decades.

At present, more institutions are training academics through distance education; collaborations among various institutions and workplaces have become more important and frequent, which positively affect the skills of teachers. The continuous development of teacher is essential for the betterment of schooling. Discussing the secondary school teacher's development, Knight (2002) argued that departments are the primary place for learning than workshops and courses. Contrary to the general concept, chairs and heads of departments need to be trained to learn and lead. Schools should focus on managerial learning and educational skills improvement. Furthermore, for optimum results, learning policies should be long term and fruits of success and blame for failure should be distributed equally between management and staff.

King (2004) concluded that collaborations between institutions, teaching staff and disciplines are important for professional development. The professional development should be considered as a normal part and should be self-directed for all professionals. Likewise, formal 
and specific training of teachers and other professionals is a key factor for the improvement of student leaning, institutions' ability and quality learning in a country. The needs of professionals differ according to their role in an institution. The use of technology can enhance the ability of teachers in all disciplines. In order to be a good teacher in all fields, it is important to develop soft skills such as dealing with students, time management, communication and a brief response to the queries from students. Most important among all is the cooperation and understanding between management and teaching staff to create a harmonized learning environment (Wood et al., 2011).

One of the crucial aspects of teacher's development and professionalism is the student oriented approach. Earley and Porritt (2014) stated that staff development has a positive impact on schools and this impact is significant where teachers and students are more attached and school management encourages the friendly learning environment. The understanding and cooperation between students and teachers provide quality of learning. It can be helpful in the measurement of skills development impact for teachers as well. Using the data of eight South African universities, Leibowitz et al. (2015) found that there are several factors which might influence the quality teaching and enhance the development level of teachers. The results suggested that various social beliefs about quality teaching such as research and teaching association, teacher's appraisal programs and the respect culture of teaching profession uptake the level of professionalism among teachers. Therefore, institute specific factors play a significant role in the professional development of its staff and also improve the quality of education.

\section{Professional Development of Accounting Professionals}

A substantial emphasis has also been given to the continuous development of accounting professionals all over the world. A special focus has been given to the instructional approaches of accounting professionals to avoid professional obsolescence in knowledge and practical skills. Rahman and Velayutham (1998) concluded that knowledge obsolescence in core and less developed areas of accounting is dealt with andragogy and pedagogy respectively. Taking the core responsibilities into account, time management is perhaps an important challenge for the accounting educators and professionals. A balanced approach is necessary to seek efficiency and productiveness in teaching, research and services.

Coppage and Baxendale (2001) suggested that academia needs to improve consistently just like business community as integrated research and services are beneficial for all parties. Synergy among three responsibilities is also helpful to deal with ethical issues of all parties involved. On a similar point, using the career stories of accounting educators from different parts of Europe, Tourna et al. (2006) proposed that awareness of core factors and understanding the development process of professionals might improve the ability of learning the complex association between teaching, research and administration. Continuous learning is an essential part of professional life and it is mandatory in the USA for accountants. Investigating the impact of this program, Wessels (2007) concluded that it is beneficial for accountants to learn and share their skills with other professionals; it is an effective tool but 
there are some constraints that reduce the positive impact of the mandatory learning.

Professional education is an integral part of accountants after joining any professional body. International Education Standard (IES 7) requires all professional accountants to be competent and develop necessary skills to fulfill their professional responsibilities. Focusing on the investigation of skill development activities in UK, Paisey et al. (2007) found that approximately $80 \%$ of accountants in public practice follow the international standards of professionalism. Most ACCA members continue to maintain competence through technical knowledge and course attendance. The rest of the accountants, i.e. $20 \%$, need to participate in technical activities to upgrade their professional status.

Exploring the link between CPD and attitude of professionals, Rothwell and Herbert (2007) suggested that attitude to CPD is associated with learning and job commitment than age, education and experience. The professional accountants have an important place in global business setup; taking their technical skills into consideration, accountants need to play a versatile role in the global economy. In order to maintain the professional contribution of accountants, CPD is the key to enhance one's value in a business organization (Lange et al., 2013).

Examining the CPD requirement perception in the Asian Pacific region, Lange et al. (2015) recorded the responses of 1310 accountants; the findings suggested that the standards of professionalism are similar because of increasing globalization but the perceptions differ in different regions. The core differences in CPD offerings are related to satisfaction with requirements, experience, quality and the appropriateness of the level of CPD, which indicates significant differences regarding CPD perceptions among accountants across the globe (Lange, et.al 2015). Exploring the literature on CPD in accountancy, Lindsay (2016) divided CPD into professional learning and career adaptability. Based on professional skills, accountants can be divided into informed, competent and complete professionals. Investigating practicing and non-practicing Chartered Accountants in Ireland, Murphy (2017) found significant differences in the perception and practice among professionals related to CPD.

\section{Professional Development of Accounting Academics}

Effective teaching and continuous skill development has become the indispensible need for all academics, especially in business schools as the academics need to deal with the students from different cultural backgrounds. The accounting and business faculty needs to be more efficient, trained and versatile to develop the same skills in the student other than host country (Lindahl \& Fanelli, 2002). Examining the development of accounting education and the factors in Ireland, Byrne and Flood (2003) cited that accounting education expanded with the economy and penetrated in the secondary school to the higher education of country. The economic boom is the key factor of accounting education in the country.

Examining CPD through survey from 66 respondents in Australia and New Zealand, Zajkowski et al. (2007) indicated that CPD is integral for academics. The main source for $\mathrm{CPD}$ is conferences, research and higher education, reading accounting education literature, 
seminars and research methods courses. The main purpose of undertaking CPD is to maintain professional competency and credibility of qualifications and improve knowledge and skills of staff. Describing the importance of accounting education research, Ravenscroft and Rebele (2008) explained that in rapidly growing economic and global world, accounting plays an important role. The accounting academics and practitioners need a proper preparation to be effective in the current modern era. In order to promote the sub fields of accounting, commitment and serious efforts are required. Without professional development, the accounting practitioners can be responsible to limit the role of accounting for society and economy.

Generally, attributes of accounting academics enhances the learning abilities of student but the negative attitude might affect the effectiveness and learning environment of educational institutes. Investigating the link between negative behavior of accounting academics and learning of student, Stout and Wygal (2010) collected the response from top ranked accounting academics; the results suggested that negative attitude, improper preparation, insufficient delivery skills, assessment mistakes and inflexible attitude of educators are the common barriers in the learning process of a classroom. Authorities and academics can improve the institute and classroom environment by avoiding such behaviors. The role of universities and workplaces is also critical in professional development of students.

With the help of interviews, Howieson et al. (2014) found that universities and professional bodies play an important role in the CPD of graduates, practitioners, educators and accountants in Australia. Although, some participants responded that universities are not the only source of development but tendency of replies indicated that institutions have the major responsibility for the professional development of graduates. Analyzing the drivers of professional effectiveness specially for accounting teachers, Wygal et al. (2014) found that commitment to work, focus of students and academics, communication skills, lecture preparation and the expertise to link the subject with practical environment are the important determinants of professional effectiveness in Australia.

Examining the experience and attitude of professional accounting faculty in the USA, Boyle et al. (2015) concluded that faculty members are satisfied from current experience in academia but largely need teaching-related training, feedback and guidance, participation in service activities and involvement in research activities to optimize the job satisfaction level and personality development. Use of modern technology in teaching and research is the key aspect of professional development of accounting and other faculties. Investigating the response to new innovative technologies in teaching, Watty et al. (2016) suggested that a significant numbers of accounting faculty members resisted the use of modern technology. Although institutions are providing sufficient technological instruments such as analytical software and latest advances to analyze the qualitative data, but the ability of faculty to embrace these advances is limited; therefore, the results suggested that the educators should be innovative than inhibitor for CPD.

\section{Concluding Remarks}

Continuous progress is the key to success in any walk of life and one cannot achieve higher 
goals without consistent professional learning. This study contains the review of available literature on CPD of accounting academics. In line with the objective of our study, the CPD literature can be categorized into three parts namely: professional development of teachers, accounting professionals and accounting academics. By and large, the existing literature suggests that effective teaching skills are important for personal and institutional development. The institutions are largely responsible for CPD of teachers; nevertheless, the teachers should respond with positive attitude and cooperative behavior towards students. Institute specific factors such as respect culture, better learning environment and appraisal from management enhances the productivity and efficiency of teachers.

CPE is the integral part of a professional associated with a professional body. Although differences exist related to the requirements, facilities, and qualities of professionalism in different workplaces, the available literature recommends that mutual understanding and learning is necessary to develop professionalism in accountants. Finally, only a few studies focused to explore the CPD of accounting academics. Generally, the literature describes the importance of accounting education and the institutional role in the development of students. The conclusion from the prior studies is that the professionals are people responsible for a stable economic position of a country; therefore, accounting academics have an important role to play in grooming of these professionals.

\section{Recommendations for Future Research}

$\mathrm{CPD}$ has been given a reasonable focus in literature but many aspects remain unexplored in the previous studies. A plenty of research work is needed to fill the vacuum; for instance: further research is needed to establish the link between CPD and promotional reward for professionals from professional bodies, institutes and government; the link between government efforts and professional improvements of academics is yet to be explored; the impact of modern technology on professionals and its possible use to uptake the CPD is an important gap to be filled; last but not least, the comparative studies of developing and developed regions on CPD are lacking in the present literature. A substantial amount of work on suggested directions will be a valuable addition to the CPD literature.

\section{References}

Berg, M. C. (2007). Continuing Professional Development - The IFAC Position. Accounting Education, 16(4), 319-327. https://doi.org/10.1080/09639280701646430

Boyle, D. M., Carpenter, B., Hermanson, D. R., \& Mero, N. P. (2015). Examining the Perceptions of Professionally Oriented Accounting Faculty. Journal of Accounting Education, 33, 1-15. https://doi.org/10.1016/j.jaccedu.2014.10.004

Byrne, M., \& Flood, B. (2003). Defining the Present and Shaping the Future: the Changing Nature of Accounting Education in Ireland. Journal of Accounting Education, 21, 197-213. https://doi.org/10.1016/S0748-5751(03)00025-3 
Cervero, R. M. (2001). Continuing Professional Education in Transition, 1981 ?2000. International Journal of Lifelong Education, 20(1-2), 16-30. https://doi.org/10.1080/09638280010008282

Chen, Y. S., Chang, B. G., \& Lee, C. C. (2008). The association between continuing professional education and financial performance of public accounting firms. The International Journal of Human Resource Management, 19(9), 1720-1737. https://doi.org/10.1080/09585190802295363

Coppage, R. E., \& Baxendale, S. (2001). A Synergistic Approach to an Accounting Educator's Primary Responsibilities. Accounting Education, 10(3), 239-246. https://doi.org/10.1080/09639280110093441

Earley, P., \& Porritt, V. (2014). Evaluating the Impact of Professional Development: the Need for a Student-Focused Approach. Professional Development in Education, 40(1), 112-129. https://doi.org/10.1080/19415257.2013.798741

Hargreaves, A. (2000). Four Ages of Professionalism and Professional Learning. Teachers and Teaching, 6(2), 151-182. https://doi.org/10.1080/713698714

Howieson, B., Hancock, P., Segal, N., Kavanagh, M., Tempone, I., \& Kent, J. (2014). Who Should Teach What? Australian Perceptions of the Roles of Universities and Practice in the Education of Professional Accountants. Journal of Accounting Education, 32, 259-275. https://doi.org/10.1016/j.jaccedu.2014.05.001

King, H. (2004). Continuing Professional Development in Higher Education: What do Academics do? Planet, 13(1), 26-29. https://doi.org/10.11120/plan.2004.00130026

Knight, P. (2002). A Systemic Approach to Professional Development:Learning as Practice. $\begin{array}{llll}\text { Teaching } \quad \text { and } & \text { 229-241. }\end{array}$ https://doi.org/10.1016/S0742-051X(01)00066-X

Lange, P. d., Jackling, B., \& Basioudis, I. G. (2013). A Framework of Best Practice of Continuing Professional Development for the Accounting Profession. Accounting Education, 22(5), 494-497. https://doi.org/10.1080/09639284.2013.824197

Lange, P. D., Jackling, B., \& Suwardy, T. (2015). Continuing Professional Development in the Accounting Profession: Practices and Perceptions from the Asia Pacific Region. Accounting Education, 24(1), 41-56. https://doi.org/10.1080/09639284.2014.1002800 
Leibowitz, B., Bozalek, V., Schalkwyk, S. V., \& Winberg, C. (2015). Institutional Context Matters: the Professional Development of Academics as Teachers in South African Higher Education. Higher Education, 69(2), 315-330. https://doi.org/10.1007/s10734-014-9777-2

Lindahl, F. W., \& Fanelli, R. (2002). Applying Continuous Improvement to Teaching in Another Culture. Journal of Accounting Education, 285-295. https://doi.org/10.1016/S0748-5751(02)00014-3

Lindsay, H. (2016). More Than 'Continuing Professional Development': A Proposed new Learning Framework for Professional Accountants. Accounting Education, 25(1), 1-13. https://doi.org/10.1080/09639284.2015.1104641

Murphy, B. (2017). Professional Competence and Continuing Professional Development in Accounting: Professional Practice vs. non-practice. Accounting Education, 26(5-6), 482-500. https://doi.org/10.1080/09639284.2016.1218780

Paisey, C., Paisey, N. J., \& Tarbert, H. (2007). Continuing Professional Development Activities of UK Accountants in Public Practice. Accounting Education, 16(4), 379-403. https://doi.org/10.1080/09639280701646554

Rahman, A. R., \& Velayutham, S. K. (1998). Instructional Approaches and the Nature of Obsolescence in Continuing Professional Education (CPE) in Accounting. Accounting Education, 7(4), 287-303. https://doi.org/10.1080/096392898331081

Ravenscroft, S. P., \& Rebele, J. E. (2008). The Importance of Accounting Education Research. Journal of Accounting Education, 26, 180-187. https://doi.org/10.1016/j.jaccedu.2009.02.002

Rothwell, A., \& Herbert, I. (2007). Accounting Professionals and CPD: Attitudes and Engagement-Some Survey Evidence. Research in Post-Compulsory Education, 12(1), 121-138. https://doi.org/10.1080/13596740601155587

Stout, D. E., \& Wygal, D. E. (2010). Negative Behaviors That Impede Learning: Survey Findings From Award-Winning Accounting Educators. Journal of Accounting Education, 28, 58-74. https://doi.org/10.1016/j.jaccedu.2011.03.001

Tourna, E., Hassall, T., \& Joyce, J. (2006). The Professional Development of European Accounting Academics: A Proposed Theoretical Framework for Future Research. Accounting Education, 15(3), 275-286. https://doi.org/10.1080/09639280600850737 
Watty, K., McKay, J., \& Ngo, L. (2016). Innovators or Inhibitors? Accounting Faculty Resistance to new Educational Technologies in Higher Education. Journal of Accounting Education, 36, 1-15. https://doi.org/10.1016/j.jaccedu.2016.03.003

Wessels, S. B. (2007). Accountants' Perceptions of the Effectiveness of Mandatory Continuing Professional Education. Accounting Education, 16(4), 365-378. https://doi.org/10.1080/09639280701646539

Wood, L. N., Vu, T., Bower, M., Brown, N., Skalicky, J., Donovan, D., et al. (2011). Professional Development for Teaching in Higher Education. International Journal of Mathematical Education in Science and Technology, 42(7), 997-1009. https://doi.org/10.1080/0020739X.2011.608864

Wygal, D. E., Watty, K., \& Stout, D. E. (2014). Drivers of Teaching Effectiveness: Views from Accounting Educator Exemplars in Australia. Accounting Education, 23(4), 322-342. https://doi.org/10.1080/09639284.2014.930692

Zajkowski, M., Sampson, V., \& Davis, D. (2007). Continuing Professional Development: Perceptions from New Zealand and Australian Accounting Academics. Accounting Education, 16(4), 405-420. https://doi.org/10.1080/09639280701646588

\section{Copyright Disclaimer}

Copyright for this article is retained by the author(s), with first publication rights granted to the journal.

This is an open-access article distributed under the terms and conditions of the Creative Commons Attribution license (http://creativecommons.org/licenses/by/4.0/). 